\title{
THE CHRISTIAN ROOTS OF EUROPE
}

\author{
Ph.D. Traian-Alexandru MIU, \\ Faculty of Orthodox Theology and Education Sciences, \\ "Valahia" University, Târgovişte, \\ ROMANIA, \\ E-mail: traianalexandrumiu@gmail.com
}

\begin{abstract}
Among the challenges that Europe must face today is the recognition and valuing its Christian roots. The Treaty on the Functioning of the European Union (The Lisbon Treaty) has avoided direct reference to the Christian roots of Europe, but has mentioned the religious heritage as the origin of the development of universal values on the basis of which the European project has been able to build its future. Many critical voices, such as that of Jacques Chirac and the Pierre Moscovici, denied the contribution of Christianity to the formation and development of the European Community. But the denial of Europe's Christian roots implies a betrayal of its culture and history. Christianity has united and given to the Europe meaning for all peoples to live in communion. Europe needs the affirmation of its Christian origins, the valorisation of moral values that have been planted from the beginning, which have developed and have been born for centuries. Europe needs Christianity to exist, to not sink, to be able to live in peace and build a civilization of good understanding between its citizens.
\end{abstract}

Keywords: Christian roots; Europe; The Lisbon Treaty; cultural heritage; unchristianizing;

\section{INTRODUCTION}

"Europa Christiana" today is facing a wave of challenges that it needs to manage and solve in the prospect of a stronger unit. In fact, a question that has troubled the minds of those who are concerned about the future of this continent, and especially of the European Union, is "what really unites us?" Is the European Union a structure that is based exclusively on economic and political factors, or what brings unity is the cultural and spiritual background? Therefore, one of the pressing problems that prompted a great deal of pro and contra reactions was that of the spiritual "roots" that led to the formation of Europe, especially the recognition of the major contribution brought by Christianity to the evolution of this continent, and of the good progress of the European project.

\section{THE TREATY ON EUROPEAN UNION (THE LISBON TREATY) AND EUROPE'S CHRISTIAN HERITAGE}

The Treaties of the European Union have over time seen some reforms that have taken into account many changes dictated by new and new challenges, such as the extension of the borders from 15 to 25 and then to 28 states. The latest revision of the European Treaties had as its starting point the European Council held in Laeken (Belgium), in 2001, lasted almost eight years, until late 2009, when the Treaty signed in Lisbon in December 2007 came into force after all Member States have ratified it. The Laeken Council made the 
decision to establish a Convention on the Future of Europe, which led to the drafting of a Treaty establishing a Constitution for Europe, also known as the European Constitution, which aimed at replacing the old European Treaties. ${ }^{1}$

The Lisbon Treaty (the Treaty on the Functioning of the European Union) reformed two European Treaties: the Treaty on European Union and the Treaty establishing the European Community.

In the "Preamble" of the Lisbon Treaty, among others, the following words are written:

"DRAWING INSPIRATION from the cultural, religious and humanist inheritance of Europe, from which have developed the universal values of the inviolable and inalienable rights of the human person, freedom, democracy, equality and the rule of law."

We must note that there is no direct reference to Christianity, but the religious heritage is mentioned as the origin of the development of the universal values upon which the European project was able to build its future, otherwise, the Article 2 of the Treaty states:

"The Union is founded on the values of respect for human dignity, freedom, democracy, equality, the rule of law and respect for human rights, including the rights of persons belonging to minorities. These values are common to the Member States in a society in which pluralism, non-discrimination, tolerance, justice, solidarity and equality between women and men prevail." ${ }^{3}$

Also, in the context of assuming, although not explicitly, the values that Christianity has promoted, in Article 3 of the same Treaty, paragraph 1, the European Union undertakes to "to promote peace, its values and the well-being of its peoples".

The Article 17 of the Treaty on the Functioning of the European Union highlights the status of churches and of non-confessional organizations within the European Union:

"1. The Union respects and does not prejudice the status under national law of churches and religious associations or communities in the Member States.

2. The Union equally respects the status under national law of philosophical and nonconfessional organisations.

3. Recognising their identity and their specific contribution, the Union shall maintain an open, transparent and regular dialogue with these churches and organisations."

The first two paragraphs are only take-overs from the Amsterdam Treaty, specifically from Declaration no. 11 of the Final Act of this Treaty. Also, the first part of the second paragraph, which recognizes the identity and contribution that Churches have brought to society, is found in the 2001 White Paper on European Governance. The novelty brought about by the Treaty on the Functioning of the European Union, of Lisbon, is that in the second part of the third paragraph, the dialogue between the European Commission and the churches within it is legally grounded. And from the use of the term "Union" we deduce that

\footnotetext{
${ }^{1}$ Sorin Șelaru, "Dialogul dintre Uniunea Europeană și Biserici", in the volume Iulia Badea-Guéritée, Alexandru Ojică (coord.), Dialogul religiilor în Europa unită, Ed. Adenium, Iași, 2015, see the web address: https://books.google.ro/books?id=1P-

$\mathrm{UCwAAQBAJ} \&$ printsec $=$ frontcover\&dq=dialogul+religiilor+in+Europa + unita\&hl=ro\&sa $=\mathrm{X} \& \mathrm{ved}=0 \mathrm{ahUKEw}$ jciZmAo6HdAhXRJFAKHTinDIsQ6AEIJzAA\#v=onepage \&q=dialogul\%20religiilor\%20in\%20Europa\%20un ita\&f=false (accessed on 04.09.2018);

$2 * * *$, "The Lisbon Treaty Commentary and Comparative Text. With an Introduction by Renato Schifani, President of the Senate", in Quaderni europei e internazionali, nr. 16, December 2009, p.75;

${ }^{3}$ Ibidem, p. 79;

${ }^{4}$ Ibidem;

${ }^{5}$ Ibidem, pp. 166-167;
} 
the dialogue is assumed by all European institutions. Indeed, in the first years after the ratification of the Treaty it was found that things did not go as churches wanted. That is why certain discussions were needed to clarify how should be applied the Article 17, paragraph 3 of the Treaty. ${ }^{6}$ Thus, the theme of the first meeting of the Committee of Representatives of the Orthodox Church to the European Union (CROCEU) (Brussels, 17 March 2010) was "Implementation of Article 17 (3) of the Treaty on the Functioning of the European Union"7. In the communiqué of the meeting, among other things, it was transmitted that "the dialogue between the political community and the Churches underscored by Article 17(3) is very welcome as a manifestation of mutual respect and as a sign of hope for a better Europe and a sustainable world" and the "dialogue in view of the implementation of Article 17(3) (is) a challenge and an opportunity for promoting the fundamental values and principles upon which European culture has based itself and along which it has developed, such as justice, peace, protection of the environment, sensitivity in front of situations of poverty and suffering, reasonable distribution of financial assets, condemnation and avoidance of all sort of violence, protection of children and women, access to education for all, standing in solidarity with one another, freedom of communication and expression, protection of religious freedom concerning both minorities and majorities and the rule of law" ${ }^{\text {. }}$.

The Orthodox Churches are struggling for a most fruitful dialogue in order to achieve a clear European gain: peace and unity. The waves of immigrants who have arrived in Europe in recent years have led some European leaders to remember the spiritual roots of Europe. The Judeo-Christian heritage must not be neglected but strengthened. We need a revaluation of the Christian moral principles that were given to Europe and the world. Without deep anchoring in a Christian experience, peace will be lost, and with it a division will occur. We want a united Europe, but in order for this to be fully realized and sustained, it requires a sustained effort and a common interest. Economic and financial factors are important, but without social stability, without a climate in which peace and good will govern, the European project will know the "taste" of failure.

\section{WILL WE SEE THE UPROOTING OF EUROPE?}

Although the Treaty on the Functioning of the European Union in Lisbon seemed, to some extent, the Christian heritage, that underpinned the formation of what is today Europe, has been valorized, although it was not clearly mentioned in the Treaty, to the joy of many, such as the President of France, Jacques Chirac, who had fought for not mentioning the Christian roots in the Preamble, many voices continued the denial process. ${ }^{9}$ Such a voice was that of the European Commissioner for Economic and Monetary Affairs, Pierre Moscovici, former Minister of Economy and European Affairs in France, who when asked what he thought about the election of a Muslim mayor of London, Sadiq Khan, a premiere in the history of Western Europe for a capital, replied: "Europe, even if it's true that on our continent a majority of the population are, let's say of Christian religion or culture, Europe is

\footnotetext{
${ }^{6}$ Sorin ȘELARU, art. cit.;

7 ***, "The first meeting of the Committee of Representatives of Orthodox Churches to the EU (CROCEU). COMMUNIQUE. Subject: Implementation of Article 17(3) of the TFEU" see the web address: http://www.orthodoxero.eu/pages/posts/the-first-meeting-of-the-committee-of-representatives-of-orthodoxchurches-to-the-eu-croceu111.php (accessed on 06.09.2018);

${ }^{8}$ Ibidem;

9 Jean-François CHEMAIN, “L'actualité des racines chrétiennes de L'Europe”, Smart Reading Press (site: srppresse.fr), published on 12.01.2018, see the web address: https://srp-presse.fr/index.php/2018/01/12/lactualitedes-racines-chretiennes-de-leurope/ (accessed on 06.09.2018);
} 
not Christian. I don't believe in the Christian roots of Europe. I believe Europe is diverse, united and diverse... There is no perfect fit between the accession to Europe and the Christian faith ... Europe - and this time I am talking about the community project, it has no Christian roots, but political ... And then, no, the 12 stars of the European flag do not symbolize the crown of the Virgin Mary! ... Those who constantly evoke the exclusiveness of Europe's Christian roots are often the heirs of the political currents that once wanted a Europe without Jews and today dream of a Europe without Muslims"10.

The denial of Europe's Christian roots implies a betrayal of its culture and history. As far as the European flag is concerned, it must be known that it was created in 1955 as a symbol of the Council of Europe, an institution that defends human rights and promotes European culture. Subsequently, the European Parliament decided in 1983 that the Council of Europe flag be used by all European Communities. In 1985, the 27th golden flag on azure background became the official emblem of the European Communities, ie the European Union today. ${ }^{11}$

The one who drew the flag was Arsène Heitz, a European official and a fervent Catholic believer. Later, he told that he was inspired to create the flag of the iconic "Miraculous Medal" of the Virgin Mary, surrounded by twelve gold stars, and a religious text describing the Virgin Mary as a woman dressed in the sun's rays, having a moon under his feet and a crown of twelve stars on his head. The blue color is associated in Christianity with the Mother of God, to whom the Orthodox and Roman Catholic religions are given a cult of over-worship. The official website of the European Union does not make any religious reference on the flag: "The European flag symbolises both the European Union and, more broadly, the identity and unity of Europe. It features a circle of 12 gold stars on a blue background. They stand for the ideals of unity, solidarity and harmony among the peoples of Europe. The number of stars has nothing to do with the number of member countries, though the circle is a symbol of unity"12. Moreover, Turkey, which is a member of the Council of Europe, has agreed to use the stars on the flag, refusing more explicit religious symbols. The Lisbon Treaty omits any reference to the flag. However, in one of the relevant Treaty Statements (No 52), sixteen countries recognize the flag as a symbol of EU membership: Belgium, Bulgaria, Germany, Greece, Spain, Italy, Cyprus, Lithuania, Luxembourg, Hungary, Malta, Austria, Portugal, Romania, Slovenia and Slovakia. ${ }^{13}$

Regarding the so-called "dream" to a Europe without Muslims, according to Mr. Moscovici's accusation (see his statement quoted above), we can say that Europeans, in Christian spirit, were as benevolent and hospitable with those who have settled in this area, regardless of their race or number, helped them to integrate and they have respected their faith and traditions. It is appropriate to be treated as well as any good host deserves: with respect, morality, gratitude, faith, etc.

\footnotetext{
${ }^{10}$ Cristian UNTEANU, "Identitatea creştină a Europei Unite, o utopie?", published on 10 September 2016, see the web address: https://adevarul.ro/international/europa/identitatea-crestina-europei-unite-utopiei1_57d3cc5a5ab6550cb88aaa12/index.html (accessed on 06.09.2018);

$1^{1}$ ***, "The European flag", on the official website of the European Union (europa.eu), see the web address: https://europa.eu/european-union/about-eu/symbols/flag_en (accessed on 07.09.2018);

12 Ibidem;

${ }^{13}$ Anne-Aël DURAND, "Le drapeau européen a-t-il une origine catholique?", in Le Monde, 12.10.2017, see the web address: https://www.lemonde.fr/les-decodeurs/article/2017/10/12/le-drapeau-europeen-a-t-il-uneorigine-catholique_5200019_4355770.html (accessed on 08.09.2018);
} 
Turkey's President Recep Tayyip Erdogan has often qualified the European Union as "a Christian club" and has demanded that a first condition for his country's accession to the European project, "not to mention the historic roots of Europe in the Constitution"14.

We can firmly say that the Christian religion played a crucial role in the construction of the European project. In fact, how can we define what the European Union is? If we define it in terms of geographic space, then Turkey has every right to be part of it. If we take into account the ethnicity or the language (Indo-European), then we should also think of the Iranians, Indians, Kurds, Armenians, etc. If the European project is an exclusively institutional one, then why does Norway refuse to join and why Britain is about to leave it? Certainly all those who deny the importance of Christianity in building a Union among the peoples of Europe should answer the questions above. ${ }^{15}$

Europe was built through the common historical experiences, on the ruins of the ancient Roman Empire, through the classical Greek heritage, having as a link the Christian religion that coalesced distant spaces and managed to build a true civilization. The inheritance of the Roman Empire continued to be present in what was called the Byzantine Empire, where Christianity had its imprint, then continuing in successive stages with the medieval period, the Renaissance, the Reformation period, then the Counter-Reformation, the Age of Lights (or The Age of Reason) and that of Romanticism. Wherever you go to Europe, even in the most isolated village, we will find symbols of Christianity, such as the Holy Cross. Also, if we analyze any political entity built after the fall of the Roman Empire, we will find that it bases its unity and legitimacy on the basis of Christianity. If we remember the difficult times of the Middle Ages, with chaos, invasions, destructions, we will easily discover that the cultural and spiritual heritage has been kept in Christian monasteries and churches. In fact, priests in churches and monasteries were the first teachers, they have been caring for the sick and cultivating philanthropy. Christianity, with all its rituals, was deeply impregnated in the everyday life of people who had the deep faith that everything that happens to them is due to divine intervention: epidemics, healing, good or bad harvests, military victories or defeats, etc. In addition to a simple analysis of the European architectural heritage, we will see as a common feature the presence of churches throughout the continent. Christianity has united and given Europe meaning for all peoples to live in communion.

French politician and essayist Philippe de Villiers, a member of the European Parliament in 2004-2009, denounced the danger of denying Christian roots and said the following words: “... this Europe in thirty years will be Islamized. Europe loses its identity, loses its spirituality, no longer knows where it comes from. Paul Valéry said, «I call Europe all the land that has been romanized, christianized and subjected to the spirit of Greek discipline». If she no longer knows this, if she does not want to acknowledge her Christian roots, Europe will be Muslim, Europe will be Islamic; she will be Islamic in thirty years. It's a matter of demography. Pierre Chaunu, Fernand Braudel, the great French historians, who

\footnotetext{
${ }^{14}$ Philippe de VILLIERS, Les turqueries du grand Mamamouchi: Adresse à Jaques Chirac, Ėditions Albin Michel S.A., 2005, see the web address: https://books.google.ro/books?id=Wf4EDAAAQBAJ\&pg=PT43\&dq=M.+Erdogan++\%C2\%ABclub+chr\%C3 \%A9tien\%C2\%BB\&hl=ro\&sa=X\&ved=0ahUKEwiGv7Kw2KjdAhULbFAKHaxiD2sQ6AEIJzAA\#v=onepage $\& \mathrm{q} \& \mathrm{f}=$ false (accessed on 08.09.2018);

${ }^{15}$ Jean-François CHEMAIN, art. cit.;
} 
were our teachers when we were students, a few years ago, said: History is demography. History is demographics!"16

Europe needs the affirmation of its Christian origins, the valorisation of moral values that have been planted from the beginning, which have developed and have been born for centuries. The dominant ideology in Europe today seems to promote the concept of "tabula rasa" among citizens, inherited from the totalitarian ideologies of the twentieth century. It seems that we are part of a process of cultural degradation and, implicitly, unchristianizing, with the ultimate goal of creating a "new", "perfect" European man, emptied of religious, cultural and intellectual heritage. This new man only has to fulfill the functions of consumer and economic agent, not to discern between good and evil, to be the exponent of ideological manipulations of all kinds, including the extremist, regardless of whether they are right or left. $^{17}$

\section{CONCLUSIONS:}

Europe is "alive" because it still draws its sap through its Christian roots. Indebtedly, the Christian heritage of this continent can not be denied, despite many voices that deny this evidence. This is not a matter of faith, but of evidence, it is a historically conclusive fact. Pierre Moscovici's assertions that he "does not believe in the Christian roots of Europe" must be considered ideological words, based on a personal judgment that does not take into account historical reality. Europe needs Christianity to exist, to not sink, to be able to live in peace and build a civilization of good understanding between its citizens. The multiculturalism does not provide the optimal way of living together, the evidence in this regard is well known. The denial of historical truth is aimed at removing Christianity to make room for a multicultural society.

\section{BIBLIOGRAPHY:}

\footnotetext{
${ }^{16}$ Philippe de VILLIERS, "Le grand déracinement", L'Observatoire de l'Europe, 18.02.2014, see the web address: https://www.observatoiredeleurope.com/Le-grand-deracinement-par-Philippe-de-Villiers_a2141.html (accessed on 06.09.2018);

${ }^{17}$ Maxime TANDONNET, "Racines chrétiennes de l'Europe: réponse à Pierre Moscovici”, in Le Figaro, 09.05.2016 (updated in 11.05.2016), see the web address: http://www.lefigaro.fr/vox/politique/2016/05/09/31001-20160509ARTFIG00084-racines-chretiennes-de-1europe-reponse-a-pierre-moscovici.php (accessed on 06.09.2018);
} 
[1] ***, "The first meeting of the Committee of Representatives of Orthodox Churches to the EU (CROCEU). COMMUNIQUE. Subject: Implementation of Article 17(3) of the TFEU" see the web address: http://www.orthodoxero.eu/pages/posts/the-first-meeting-of-the-committeeof-representatives-of-orthodox-churches-to-the-eu-croceu111.php (accessed on 06.09.2018); [2] ***, "The Lisbon Treaty Commentary and Comparative Text. With an Introduction by Renato Schifani, President of the Senate", in Quaderni europei e internazionali, nr. 16, December 2009, p.75;

[3] ***, "The European flag", on the official website of the European Union (europa.eu), see the web address: https://europa.eu/european-union/about-eu/symbols/flag_en (accessed on 07.09.2018);

[4] CHEMAIN, Jean-François, "L'actualité des racines chrétiennes de L'Europe", Smart Reading Press (site: srp-presse.fr), published on 12.01.2018, see the web address: https://srppresse.fr/index.php/2018/01/12/lactualite-des-racines-chretiennes-de-leurope/ (accessed on 06.09.2018);

[5] De VILLIERS, Philippe, "Le grand déracinement", L'Observatoire de l'Europe, 18.02.2014, see the web address: https://www.observatoiredeleurope.com/Le-grandderacinement-par-Philippe-de-Villiers_a2141.html (accessed on 06.09.2018);

[6] Idem, Les turqueries du grand Mamamouchi: Adresse à Jaques Chirac, Ėditions Albin Michel S.A., 2005, see the web address: https://books.google.ro/books?id=Wf4EDAAAQBAJ\&pg=PT43\&dq=M.+Erdogan++\%C2\% ABclub+chr\%C3\%A9tien\%C2\%BB\&hl=ro\&sa=X\&ved=0ahUKEwiGv7Kw2KjdAhULbFA KHaxiD2sQ6AEIJzAA\#v=onepage\&q\&f=false (accessed on 08.09.2018);

[7] DURAND, Anne-Aël, "Le drapeau européen a-t-il une origine catholique?", in Le Monde, 12.10.2017, see the web address: https://www.lemonde.fr/lesdecodeurs/article/2017/10/12/le-drapeau-europeen-a-t-il-une-originecatholique 5200019 4355770.html (accessed on 08.09.2018);

[8] ȘELARU, Sorin, "Dialogul dintre Uniunea Europeană și Biserici", in the volume Iulia Badea-Guéritée, Alexandru Ojică (coord.), Dialogul religiilor în Europa unită, Ed. Adenium, Iași, 2015, see the web address: https://books.google.ro/books?id=1PUCwAAQBAJ\&printsec=frontcover\&dq=dialogul+religiilor+in+Europa+unita\&hl=ro\&sa= $\underline{X}$ \&ved=0ahUKEwjciZmAo6HdAhXRJFAKHTinDIsQ6AEIJzAA\#v=onepage\&q=dialogul \%20religiilor\%20in\%20Europa\%20unita\&f=false (accessed on 04.09.2018);

[9] TANDONNET, Maxime, "Racines chrétiennes de l'Europe: réponse à Pierre Moscovici", in Le Figaro, 09.05.2016 (updated in 11.05.2016), see the web address: http://www.lefigaro.fr/vox/politique/2016/05/09/31001-20160509ARTFIG00084-racineschretiennes-de-1-europe-reponse-a-pierre-moscovici.php (accessed on 06.09.2018);

[10] UNTEANU, Cristian, "Identitatea creştină a Europei Unite, o utopie?", published on 10 September 2016, see the web address: https://adevarul.ro/international/europa/identitateacrestina-europei-unite-utopiei-1_57d3cc5a5ab6550cb88aaa12/index.html (accessed on 06.09.2018); 